\title{
Examining Race Privilege in America: The Preservation of Whiteness through the Systematic Oppression of African-Americans
}

By Justin Selner

\begin{abstract}
The prevailing assumption that race-relations have equalized in America is largely based on an incorrect and misinformed understanding of current socio-economic policies and public behaviors. The continued racialization and discrimination towards African-Americans may be linked to strategic efforts that seek to preserve the dominance and authority of whiteness. This paper examines such claims within the context of the post civil rights movement, with specific attention given to the media, education system, and implementations of social justice.
\end{abstract}

Emerging in the 1950's and readily gaining credibility and support, the notion of race as a scientific indicator of concrete, physiological differences between human beings, has largely been rejected. Academics and individuals who have dedicated their work to the promotion of racial differences have essentially failed to depict any unique behavioral traits that are specific to a particular ethnic group. Bruce Baum, Professor of Political Science at the University of British Columbia reaffirms this belief, citing that, "more and more scholars have concluded that the zoological concept of race cannot meaningfully be applied to the physiological differences among human beings. That is, there are no human races in the old biological sense." Yet, the discourse surrounding racial implications and societal treatment of race continues to persist with contested fervor and passion.

Stemming from this unsubstantiated notion of race, arises a

${ }^{1}$ Bruce Baum, The Rise and Fall of the Caucasian Race: A Political History of Racial Identity. (New York: New York University Press, 2006), 193. drastically altered understanding through which the process of racialization is intertwined with motivations of power, subjugation, and domination. That is, the politicization of race has discreetly continued under the veil of specific policies, practices, and labels that exist to ensure the segregation between the powerful and weak. When placed in the framework of the modern American society, this dichotomy has acted to perpetuate the traditional distinction between white individuals and those visually categorized as black. Although operating under the guise of racial equality and equal opportunity for all, significant and debilitating discrepancies exist between the two "races" through which members of the black community endure further suffering. Moreover, these injustices continue unacknowledged, hidden by the widely misinformed societal assumption that race relations have equalized, offering fair opportunities for everyone regardless of physical characteristics. However, one simply needs to consider facts that exemplify this striking racial division in the United States: "On 
average, people of colour have eight cents for every dollar of white wealth."

Despite such glaring instances of structural racism, this paper will argue that the pervasive inequality and discrimination that continues to plague American society is not a racially systemic phenomenon. Rather, it is both embedded and perpetuated through a myriad of processes and policies that discretely seek to preserve the relatively dominant and dictatorial capabilities of the "white" race. To provide a more narrow and succinct framework for analysis, the said thesis will be argued within the context of the post civil rights movement, with specific focus given to African-Americans. This contention will be developed through the examination of racially divisive areas such as the media and the education system. Finally, the paper will conclude with a joint analysis of the justice system and immigration.

Prior to delving into the racialized interaction between white and black individuals, it may be useful to further elaborate upon "whiteness" and how one is to understand its usage throughout the paper. Rather than simply describing the physical characteristics or ethnic features of a given culture, whiteness may best be understood as a social construction that is employed to secure political and economic power. At the same time, it

${ }^{2}$ Amaad Riviera, Jeannette Huezo, Christina Kasica, and Dedrick Muhammad, "State of the Dream 2009: The Silent Depression," United for a Fair Economy, 2009, http://www.faireconomy.org/files/pdf/state of_dream_2009.pdf. may be assumed that whiteness suppresses and acts to disenfranchise those who do not fit Caucasian traits. John Fiske aptly describes whiteness as the, "strategic deployment of power or the space from which a variety of positions can be taken."3 To elaborate, Ruth Frankenberg adds that, "whiteness is constructed precisely by the way in which it positions others at its borders." From this, it can easily be derived that whiteness is employed within a relational context in which the racialized, black minority is maliciously portrayed to invoke emotions of fear, insecurity, and anxieties as to the security of the nation. ${ }^{5}$ Speaking to this conclusion, Franz Fanon notes that whiteness has sought to dehumanize the "other" and continually reassert dominance through the internalization of guilt. ${ }^{6}$ By this, Fanon may be suggesting that the internalization of guilt by the specific, targeted other, may act as a means by which whites can continue their tirade of oppression, albeit in a less obvious and more socially acceptable manner.

Potential criticisms that stand to debase this depiction of whiteness may readily cite instances of racism towards the Irish and the appalling oppression they endured, despite being

\footnotetext{
${ }^{3}$ John Fiske, Media Matters: Race and Gender in U.S. Politics (Minneapolis: University of Minnesota Press, 1996), 42.

${ }^{4}$ Ruth Frankenburg, White Women, Race

Matters: The Social Construction of

Whiteness (Minneapolis: University of

Minnesota Press, 1993), 237.

${ }^{5}$ John Gabriel, Whitewash: Racialized Politics and the Media (New York: Routledge, 2005), 15.

${ }^{6}$ Franz Fanon, Black Skin, White Masks

(London: Pluto, 1986), 129.
} 
characterized as white. Although a noteworthy query, Marylin Frye has coined the term "whiteliness" to alleviate such confusion and provide a blatant distinction as to the attributes commonly associated with whiteness. Frye delineates between the two, noting that whiteness simply describes certain physical traits, whereas whiteliness may be referenced to white domination and their socially constructed supremacy. ${ }^{7}$ Despite these linguistic differences, for the remainder of the paper, the implications of the term "whiteness" are to be considered synonymous with Frye's notions of "whiteliness." This is largely due to the context and racial dichotomy through which this paper will traverse: Namely, whiteliness will not be used to distinguish between varying groups of white citizens, as the specific contention of the paper is defined by the relationship between African-Americans and white individuals.

\section{Media}

One of the ways in which AfricanAmericans continue to be oppressed and confined to the lower eschlons of society, has occurred through strategically manipulated media portrayals that aim to preserve the authoritative and hegemonic position of the white elites. The ability for such a destructive process to so readily and easily occur, without significant public outcry, may largely be attributed to the discreet and conspicuous deployment of

${ }^{7}$ Marilyn Frye, "White woman feminist," in Overcoming Racism and Sexism, ed. Linda A. Bell and David Blumenfeld (Lanham: Rowman \& Littlefield Publishers Inc, 1995), 116. racialization and discriminatory practices that subtly blend into the mundane, everyday constructions of culture. ${ }^{8}$ As such, various racialized instances throughout the political, economic, and policy realms have been accepted as normal and legitimate. A simple, yet widely prevalent example may be seen in the enormous capital and social inequalities, where blacks have been consumed with financial despair and positioned as outside of respectability. ${ }^{9}$ This has instigated a certain degree of complacency on the part of both public and private officials, in which the failure to openly critique the blatant saliency of whiteliness has served to solidify an aura of helpless acceptance towards the impoverished and paralyzing conditions of the black existence.

Noam Chomsky and Edward Herman have constructed a "propaganda model" that seeks to explain the mechanisms and processes enacted by those who subscribe to whiteness, to ensure their continued dominance and the guaranteed manifestation of specific political and economic interests, as alluded to above. ${ }^{10}$ Encompassed within this framework of understanding are particular filters that have censored and silenced the claims of the most vulnerable and marginalized members

\footnotetext{
${ }^{8}$ Gabriel, Whitewash, 11.

${ }^{9}$ France W. Twine, A White Side of Black

Britain: Interracial Intimacy and Racial Literacy (London: Duke University Press, 2010), 38.

${ }^{10}$ Edward S. Herman and Noam Chomsky, Manufacturing Consent: The Political Economy of the Mass Media (London:
} Verso, 1994), 1. 
of society. ${ }^{11}$ Perhaps not as obvious as traditional censorship tactics, one of the methods voiced by Chomsky and Herman simply references the overwhelming, crushing, and allconsuming size of the major media outlets and corporations. This global reach and influence may be best exemplified through corporate media networks such as Viacom, that operates with "brands represented in more than 562 million households in 161 countries and territories." 12

Heavily fueled through globalization, instances of both time and space have been greatly reduced, thus fostering an increased global interconnectivity. Subsequently, powerful media moguls such as Viacom have strived to act within this new technological atmosphere. Specifically, Viacom has attempted to assert an expansive, global influence over information, drowning out the claims of struggling African-Americans. ${ }^{13}$ Moreover, the sheer economic and industrial capacity of an oligarchy of Western media giants has created an almost unconquerable and prohibitive barrier to entry. As such, standard citizens lack both the power and finances to effectively disseminate their claims for sustenance and basic equalities. ${ }^{14}$

However, given the prevalence and relative ease of access to

\footnotetext{
${ }^{11}$ Gabriel, Whitewash, 21.

${ }^{12}$ Viacom Media Networks, "Our Brands," Reaching Our Global Audience, http://www.viacom.com/ourbrands/Pages/de fault.aspx.

${ }^{13}$ Gabriel, Whitewash, 21.

${ }^{14}$ Ibid.
}

computers and the internet (at least within the American context), one may question the validity of the above presented argument. Specifically, if individuals can easily voice their opinions and concerns via the internet, it may be an exaggeration, perhaps even dated, to claim that corporate media giants have usurped the arena for racial equality and one's right to freely express his or her most pressing emotions. Despite the noteworthy merits of such criticisms, it will be argued that it is irresponsible and naive to assume that there are other avenues of media (free from white, corporate control) through which discriminated populations may easily respond to oppressive policies and ignite effective, reactionary change. It is necessary to qualify that this position is presented in the context of assuming a single, African-American individual with an average income and position within society. What this is attempting to convey is the relative weakness and inability of a lone black individual to combat an oppressive white discourse through methods such as blogging on the internet. While organizations such as the National Association for the Advancement of Colored People (NAACP) offer a collective and unified front to combat the debilitating ideology of whiteness, it is an added hurdle to simply voice a claim that may receive no genuine attention. That is to say, disenfranchised AfricanAmericans who are simply trying to provide the bare necessities for their families may likely not have the time, energy, or resources to act within an organization such as the NAACP to assert a claim to their humanity. This silence towards whiteliness may reassert the destructive cycle of racialization and oppression, with the 
potential consequence of maintaining the unequal power relations between black people and white people. ${ }^{15}$

Media representations of black and white individuals also serve to cement the racial status quo through grossly exaggerated and often fictitious portrayals of black men. Consider various high profile homicide cases such as that of Charles Stuart and Susan Smith, in which the actual killers had accused a black man of committing the alleged crime so as to divert suspicion. ${ }^{16}$ In this scenario, the media immediately responded by widely disseminating images of a savage, black killer, while also reengaging discussions pertaining to the death penalty. ${ }^{17}$ This portrayal of a ravenous, violent, black race wrongly reinforces notions of an inherent black criminality and depicts a line by which innocence and guilt may be defined by race. Further implications of an inherent black criminality suggest a severe, if not impossible barrier to change; an assumption that black individuals are naturally more violent and society has to act accordingly (such as racial profiling and stereotyping). However, as cautioned by Cresswell, "the distinction is fine but far-reaching: once we talk about nature we think about the incapacity for change." ${ }^{18}$ Again, this

15 Ann Phoenix, "I'm white - so what?' The Construction of Whiteness for Young Londoners," in Off White, ed. Michelle Fine, Lois Weis, Linda Powell Pruitt, and April Burns (New York: Routledge, 1997), 196.

${ }^{16}$ Steve Garner, Whiteness: An Introduction (New York: Routledge, 2007), 20.

${ }^{17}$ Ibid.

${ }^{18}$ As cited in Frances E. Kendall, Understanding White Privilege: Creating understanding condemns AfricanAmericans to a perpetually devalued societal position and may imply a continually oppressive, racialized future, given the media's supposition that the black race is inherently violent, aggressive, and barbaric.

Finally, a further examination of the way in which the media has been framed to cement the structurally oppressive and authoritarian capabilities of whiteness is evident in the media's racialized portrayal of drug use. Enshrined within this presentation is a deceiving and falsely construed misconception that black individuals heavily outweigh the percentage of drug use by white citizens. ${ }^{19}$ Ironically, the data from the New York Correctional Association indicates a striking conclusion: Nearly ninety percent of drug-related prisoners are either Latino or black, despite the fact that white individuals consume an incomparably greater amount of narcotics. ${ }^{20}$ This contradictory representation of white supremacy and an inherent black vulgarity also appeared in the newspaper publications after Hurricane Katrina demolished New Orleans. Various papers depicted and described white men as "finding" food in destroyed grocery stores, while black men partaking in the exact same act were described as "looting" and "stealing."

Pathways to Authentic Relationships Across Race (New York: Routledge, 2006), 37.

${ }^{19}$ Melanie Bush, Everyday Forms of

Whiteness: Understanding Race in a "PostRacial" World (Lanham: Rowman \& Littlefield Publishers Inc, 2011), 194.

${ }^{20}$ As cited in Ibid.

${ }^{21}$ Kendall, Understanding White Privilege, 82.

The Agora: Political Science Undergraduate Journal Vol. 2 No. 2 (2012) 
Therefore, without consideration or knowledge of this illuminating data, one may adequately reason that such racialized characterizations will continue to be reproduced, substituting a decontextualized and depoliticized analysis to maintain white hegemony. ${ }^{22}$

\section{Education:}

W.E.B. Du Bois (1979) once harkened that education should be made available to all individuals, regardless of race. ${ }^{23}$ While it is an assumed fact that primary and secondary education are easily accessible, this facade quickly erodes when considering the extent to which the educational quality differs for the racialized enclaves of society. Often times, certain policies that augment this divide are not represented as overt attacks or observable assaults on the livelihood of Africa-American individuals but rather, as undocumented repercussions, ignored by the public majority. A striking example to bolster this claim is that of the New Orleans educational reforms and efforts to institute a "portfolio school district." 24 Easily paralleled to American chartered

${ }^{22}$ Bush, Everyday Forms of Whiteness, 194. ${ }^{23}$ W.E.B. Du Bois, Black Reconstruction in America: 1860-1880 (West Hanover: Atheneum Publishers, 1979), 637-669.

${ }^{24}$ Kristen L. Buras, "Race, Charter Schools, and Conscious Capitalism: On the Spatial Politics of Whiteness as Property (and the Unconscionable Assault on Black New Orleans)," Harvard Educational Review 81, no. 2 (2011): 302,

http://www.metapress.com.login.ezproxy.lib rary.ualberta.ca/content/6142343qqw360j03/ $? p=934 a 793 b 7711450690 b 360889 f c 3098 f \&$ $\mathrm{pi}=8$. schools, Paul Hill describes the basis of a portfolio school district as involving traditional operations, yet sacrificing a portion of autonomy, as the school will be contracted to private investors. In turn, it is assumed that these private investors will hold the specific schools accountable to high standards of performance. ${ }^{25}$ Free from the shackles of government regulations and labour unions, one may argue that such a system of educational reform would increase efficiency and reduce costs. This would primarily be achieved through the delivery of a nonstandardized curriculum, while also allowing families the "freedom" to send their children to the schools that produce the best academic performances. $^{26}$

While advertised as a means to promote steady increases in the quality of education, this marketization of the New Orleans' educational system may best be understood as a form of accumulation by dispossession. That is to say, white entrepreneurs have appropriated and commodified a crucial aspect necessary for the functioning and well-being of the impoverished black community: public schools. ${ }^{27}$ Once demolished, the education system rapidly descended into a competitive whirlwind in which families struggled and fought to get their children into the best possible school. Unfortunately, nearly all of the schools had a significant cost to entry and incredibly small class sizes that served to limit enrollment from the struggling black communities.

\footnotetext{
${ }^{25}$ As cited in Ibid.

${ }^{26}$ Ibid.

${ }^{27}$ Buras, "Race, Charter Schools, and Conscious Capitalism," 304.
} 
Consequently, the majority of black children that were not able to matriculate in one of the portfolio schools were then forced to attend state-run schools in the Recovery School District - largely considered to be a, "dumping ground" for those unable to attend the charter schools. ${ }^{28}$ The summation of this gross exploitation, economic segregation, and veiled attack on the black communities is best conveyed by Cheryl Harris: "white identity has enabled its possessors to use and enjoy a host of benefits and assets and to exclude communities of color from such entitlements." ${ }^{29}$ Thus, although publicly portrayed as a means to benefit the educational experience for all, the economic implications of the portfolio school district sought to discreetly, yet systematically reproduce a system of societal inequality, marked by white exclusivity and black discrimination.

Beyond the context of the New Orleans educational system, the negative and detrimental consequences of sinister, racialized educational reform, is further exemplified by budget cuts to public education and the subsequent barriers obstructed towards the pursuit of higher education. When funds, initially allocated to the promotion of higher (secondary, post-secondary, etc.), public education, are cut, there are significant repercussions that reverberate throughout every level of society. For instance, due to the primary reliance on public funding, in times of fiscal constraint and large budget cuts, public institutions must resort (albeit,

${ }^{28}$ Ibid., 303.

${ }^{29}$ As cited in Ibid., 304. unwillingly) to increasing tuition fees. ${ }^{30}$

As a result, the largest portion of individuals that will be affected are those who comprise the lower economic eschlons of society; namely, those of the black community. Subsequently, this may instill and reproduce a cycle in which the majority of individuals attaining higher education are white. This abundance of "whiteness" is thus mirrored in the composition of individuals responsible for the formulation and construction of policies, and typically fails to address the hardships endured by black individuals. Ironically, had the racially homogenous policy makers been less jaded and removed from the daily realities plaguing various African-American families, benefits may stand to be generated for the greater society at large. That is, if public education was to be made more accessible for everyone, the American market would have access to an arguably much larger workforce, intellectually equipped to contribute to the betterment of society. Moreover, the increased earnings to the marginalized sectors may act to elevate the status of black individuals and substantiate their previously ignored, yet pertinent cries for change.

Granted these obvious injustices prevalent in the educational system, policies such as affirmative action have been pursued in an attempt to combat racial inequalities. Consider this response in the context of postsecondary admissions: In the 1990s, the University of California, Berkley, the University of Texas, Austin, and the University of Wisconsin, Madison, all took measures to adopt a racially

${ }^{30}$ Bush, Everyday Forms of Whiteness, 186.

The Agora: Political Science Undergraduate Journal Vol. 2 No. 2 (2012) 
conscious admissions process. ${ }^{31}$

Generally speaking, this evolution away from a colorblind approach (in which university applicants were generally compared on a quantitative basis) involved a shift towards individualized reviews with the potential use of formulas to account for minority students. ${ }^{32}$ While these actions had the welcomed benefit of deepening campus diversity and supporting higher education opportunities for those most vulnerable in society, affirmative action policies also faced significant controversy.

While it had initially appeared as a victory against racism, affirmative action policies that directly sought to mitigate traditionally racialized and gendered institutional practices, had the undesirable repercussion of further fragmenting society. That is to say, these anti-discriminatory laws became highly contested by white individuals, resulting in a Supreme Court ruling (University of California, Davis v. Bakke) that stipulated no preferential treatment should be given on the basis of race, gender, ethnicity, etc. ${ }^{33}$ When coupled with a reduction in government funding to social projects and economic developments that sought to rein in

${ }^{31}$ Daniel N. Lipson, "The Resilience of Affirmative Action in the 1980s: Innovation, Isomorphism, and Institutionalization in University Admissions," Political Research Quarterly 64, no. 1 (2011): 136, http://ehis.ebscohost.com.login.ezproxy.libr ary.ualberta.ca/eds/pdfviewer/pdfviewer?sid =18bcb162-1410-4fbd-ae42-

2662bed $85365 \% 40$ sessionmgr $113 \&$ vid $=9 \&$ hid $=103$.

32 Ibid.

${ }^{33}$ Ibid., 137. racial inequalities, the prior optimism that had circulated within programs of affirmative action, began to erode. Hence, Steve Martinot espouses that, "it was in this context of movement atomization that white populism grew and provided the base for repeal of affirmative action programs." 34 Therefore, what is to be taken from this discussion is that while potential benefits stand to be gained from policies of affirmative action, they often accompany intricate complexities that may tear at the already delicate social cohesion of a given community. Most importantly, it is crucial to recognize that it is both politically dangerous as well as a complete fallacy, to assume that race relations have equalized given the emergence of such socially progressive legislation. Rather, this generalized and far reaching attack on education may be seen as an attempt of whiteliness to reduce, belittle, and essentially exile the black community into the impoverished gutters of society.

\section{Crime and Policing:}

For the purpose of this paper, when discussing issues of structured discrimination and racialization within the justice system, the analysis will primarily focus on patterns of policing and the American prison system. Most notably, this method of racial segregation may be found in the security and patrolling mechanisms by which police officers categorize potentially dangerous individuals. However, this method of labeling has

\footnotetext{
${ }^{34}$ Steve Martinot, The Machine of Whiteness: Studies in the Structure of Racialization (Philadelphia: Temple University Press, 2010), 80.
}

The Agora: Political Science Undergraduate Journal Vol. 2 No. 2 (2012) 
largely been saturated with racial significance that has sought to establish a means of profiling in which blacks are associated with crime and whites with innocence. $^{35}$ The striking fact that stands diametrically opposed to this divisive and racialized method of profiling, is the statistical evidence that clearly reveals black individuals as being no more likely to commit a felony than a white individual: "Blacks were nine times as likely as whites to be stopped by the police in New York City in 2009, but, once stopped, were no more likely to be arrested." ${ }^{36}$ Despite this revealing fact, the racial divide persists, in which police officers continue to employ racial profiling to "best" identify potential suspects.

This form of racial classification has also established a definition of what the majority of the American population think a criminal looks like. That is, one typically does not imagine a criminal to be a white, educated person, despite the evidence that black individuals are no more likely to commit a crime than their white counterparts. ${ }^{37}$ As such, blacks continue to endure the humiliation and personal violation that results from the prominent, yet fictitious construction that portrays AfricanAmericans as inherently violent, dangerous, and criminal.

Developing in tandem with this greatly distorted and racialized presentation as to what aesthetically constitutes a potential criminal is the increased allocation of funding that prioritizes prisons over education. Not

\footnotetext{
${ }^{35}$ Bush, Everyday Forms of Whiteness, 193.

${ }^{36}$ Ibid., 191.

${ }^{37}$ Ibid., 192.
}

only does this reassert the dominance of whiteness, but it also decreases opportunities of social mobility for the black underclass. Specifically, emerging in the 1980s and 1990s, American government funding patterns began to prioritize prisons over schools, justified under the guise of a need to promote neighborhood safety. ${ }^{38}$ However, these decisions also had monumental implications for black individuals, as it strategically sought to enforce their subjugation to a dominant white force. To elaborate, consider the statistic that highlights that black individuals (both male and female) are less likely to commit crimes than the national average. ${ }^{39}$ Yet, as alluded to in the previous paragraph and reinforced by Naomi Klein, blacks have dramatically higher rates of incarceration. ${ }^{40}$ Consider the striking conclusions offered by the Kaiser Family Foundation:

The percentage of young African American men in prison is nearly three times that of Hispanic men and nearly seven times that of white men. While African American men represent $14 \%$ of the population of young men in the U.S., they represent over $40 \%$ of the prison population. ${ }^{41}$

\footnotetext{
${ }^{38}$ Ibid., 195.

${ }^{39}$ Ibid.

${ }^{40}$ Naomi Klein, "Minority Death Match: Jews, Blacks, and the 'Post-racial' Presidency," Harper's Magazine, September 2009, 57.

${ }^{41}$ Kaiser Family Foundation, "Race, Ethnicity, and Health Care Fact Sheet," 2006, http://www.kff.org/minorityhealth/upload/ 7541.pdf.
} 
Therefore, given this data, it may be reasoned that such policies reflect an assumption that more blacks will continue to populate jails in a relatively larger proportion than educational institutions. Moreover, recall the generalized premise that an increased education may offer an avenue by which black individuals may ameliorate their longstanding societal oppression. Thus, it may be understood that the transfer of funds away from public education towards the prison system is simply a continuation of this segregation and a reinforced attempt to maintain the dominant power position of whiteness.

In terms of providing a holistic consideration of the racial prevalence rampant throughout the justice system, a further, gendered analysis of the data may reveal the destructive presence of whiteness, while also revealing additional levels in which discrimination has manifested. Specifically, consider the enlightening data that exemplifies the significant difference between the incarceration rates of women of colour and white women:

Women of color comprise 40 percent of those in street prostitution, 55 percent of those arrested, and 85 percent of those in jail ... an African-American woman jailed for sex offenses will on average spend almost twice as much time in jail as a white woman. ${ }^{42}$

${ }^{42}$ As cited in Imani Perry, More Beautiful and More Terrible: The Embrace and Transcendence of Racial Inequality in the United States (New York: New York University Press, 2011), 115.
Therefore, as concluded from the data previously presented, it is again evident that the justice system (in reference to the composition of prison inmates) is highly racialized and grossly favours the preservation of whiteness. However the example given above also depicts a further rung of subjugation, through the blatant racialization of gender. Imani Perry expands upon this acknowledgment in her description that, "the Black 'working girl' is more vulnerable to the crimes of others and pays more for hers." ${ }^{33}$ Thus, constructions within the prison system have sought to bolster white hegemony through not only standard racism, but also through a conscious, gendered assault on women of colour.

Immigration is yet another front on which the repressive actions of whiteliness have sought to maintain racial superiority, while trouncing opportunities for advancement and success within the black populous. Despite America's relatively stringent immigration policies, there exists several discrepancies within these laws that reveal significant racial discrimination. More explicitly, it will be argued that colored immigrants (from the Dominican Republic, Haiti, or elsewhere) are treated much worse than other nonwhite immigrants. This is directly conveyed in the comparison between how Cuban and Haitian immigrants are treated.

Black, Haitian immigrants are exposed to incomparably greater political and racial scrutiny than those individuals migrating from Cuba. ${ }^{44}$ This

${ }^{43}$ Ibid.
${ }^{44}$ Ibid., 107.

The Agora: Political Science Undergraduate Journal Vol. 2 No. 2 (2012) 
vast distinction in treatment has literally translated into one group (Cubans) being allowed to immigrate, with the other (Haitians) being forced to return to their country of origin. Charles Ogletree succinctly conveys this enormous disparity in his summation that, "Cuban refugees, most of whom are white, are granted citizenship, while black Haitians are repatriated." ${ }^{45}$ From this realization, one can easily ascertain that certain United States immigration policies may have been invoked with the primary intention of refusing black individuals, while selectively expanding the hegemonic, white membership. Noel Cazenave accurately defines this abolition or extermination of colored immigrants as "immigration-focused race population control" by which immigrants of a certain race (in this case, black) are refused citizenship. ${ }^{46}$ This allows for the construction of the most ideal population in which the composition of the racial demographics solely, or predominantly contribute to the promotion of a dominant white discourse.

Additionally, this refusal of black immigrants may be based on the notion that such individuals are inherently dangerous to the security and well-being of the nation-state. ${ }^{47}$ While Cazenave notes that a pervasive belief of inherent white superiority has motivated many to simply reckon that blacks do not belong, the overarching political justification may

\footnotetext{
${ }^{45}$ As cited in Ibid.

${ }^{46}$ Noel A. Cazenave, The Urban Racial

State: Managing Race Relations in

American Cities (Lanham: Rowman \&

Littlefield Publishers Inc, 2011), 208.

${ }^{47}$ Perry, More Beautiful and More Terrible, 107.
}

be more complex. ${ }^{48}$ The more acceptable argument may be based on the need for security of the nation-state, even if the threat of the foreigner is not real. Drawing on the theoretical framework presented by Dhamoon and Abu-Laban, the invocation of racialization seeks to legitimate actions of re-nationalization that, in the current context of the United States, reinforces and barricades whiteness from any opposition that may threaten their dominating position of power. ${ }^{49}$ This socially constructed process has largely unfolded despite the lack of evidence as to the stereotyped "threat" presented by the black immigrants. Thus, the implementation of this racialized discourse, depicting black immigrants as dangerous and threatening, may have simply been a guise to construct a national identity that maintains white elitism and superiority. ${ }^{50}$

One stark objection that stands contrary to the arguments presented through the paper is the partial rise of a supposed African-American middle class, further bolstered by the election of President Barack Obama. Voiced more bluntly, if all of the prior discussed examples were truly relevant, how does one account for this assumed surge in the political, economic, and social status of black individuals? Furthermore, nearly half of white Americans are under the assumption that black individuals are better off now as opposed to five

\footnotetext{
${ }^{48}$ Cazenave, The Urban Racial State, 163.

${ }^{49}$ Rita Dhamoon and Yasmeen Abu-Laban,

"Dangerous (Internal) Foreigners and Nation-Building: The Case of Canada," International Political Science Review 30, no. 2 (2009): 167.

${ }^{50}$ Ibid.
} 
years ago, simply because of the racial profile of the President. ${ }^{51}$ These comments warrant significant consideration given statistics that further cite an enormous increase in the amount of African-Americans occupying a government job: "Although African Americans compose less than $15 \%$ of the population, they currently make up $35.8 \%$ of the workforce in the Department of Education and $38 \%$ in the Department of Housing and Urban Development (U.S. Office of Personnel Management). ${ }^{52}$

Despite the obvious message of racial equality conveyed by the election of a black president, a more critical analysis reveals that discrimination and inequalities are still just as rampant. Specifically, in the post-civil rights period, many African-Americans migrated to racially diverse urban centres in search of better work. ${ }^{53}$ However, given the current environment of wide-scale globalization and neoliberal policies, jobs have been exported abroad, transforming America into a primarily service-based industry. Most notably, the consequence of this evolution revolves around the radically disproportionate relationship between the relative minimum wages paid and

${ }^{51}$ Pew Research Center, A Year After Obama's Election: Blacks Upbeat about Black Progress, Prospects (Washington, DC: Author, 2010), 11.

${ }^{52}$ As cited in Felix Germain, “'Presidents of Color,' Globalization, and Social

Inequality," Journal of Black Studies 40, no. 3 (2010): 456,

http://jbs.sagepub.com.login.ezproxy.library .ualberta.ca/content/40/3/445.

${ }^{53}$ Ibid., 455. the elevated costs of living in urban America. ${ }^{54}$ These hardships have reverberated throughout the entire African-American community, as the majority of the black population resides in urban America. ${ }^{55}$ Whereas white individuals living in a rural setting may be able to survive on the marginal wages, the contrasting result of these political and economic responses have facilitated an increase in AfricanAmerican poverty. ${ }^{56}$

In more extreme cases, the presumption that there has been a rise of a black middle class, has precipitated a powerful, albeit questionable, discourse in which whiteliness is depicted as suffering from this new era of supposed racial equality. ${ }^{57}$ This manifestation of white victimology seeks to foster a political realization that reductions in racial inequalities conjure a competitive threat to the hegemonic position of white people. ${ }^{58}$ By way of response, one may infer that this framing of a racial competition may support the flourishing of a dichotomy of eternal racial segregation that presupposes the inability for both whites and blacks to equally co-exist.

Moreover, in opposition to the criticisms of white victimology, it will be argued

\footnotetext{
${ }^{54}$ Ibid., 456.

${ }^{55}$ Ibid.

${ }^{56}$ Ibid.

${ }^{57}$ David Gillborn, "Coincidence or conspiracy? Whiteness, policy and the persistence of the Black/White achievement gap," Educational Review 60, no. 3 (2008): 234,

http://www.informaworld.com.login.ezprox y.library.ualberta.ca/openurl?genre $=$ article $\&$ $\mathrm{id}=$ doi:10.1080/00131910802195745.

${ }^{58}$ Ibid.
} 
that the most substantial policies invoked during the Obama administration have actually been laden with racial inequality, further supporting notions of whiteliness and hegemony.

For instance, Germain notes that, "Obama's administration has pumped billions of dollars into financial institutions whose hierarchical structures feature entrenched gender and racial inequality." ${ }^{59}$ In reference to the black poverty in urban America, Obama's decision to support the capitalist enterprises and economic hegemony of the financial sector does not provide any condolences for the racialized inhabitants of these inner cities. More importantly, the dismal approval rate of bank loans for black individuals has continued in the traditional discriminatory and withholding manner. Consequently, this has erected a substantial and unnecessary blockade for black individuals seeking to attain a better financial future. ${ }^{60}$ Therefore, the notion of providing a bail-out to banks, and subsequently, to the white elites who partially orchestrated the financial disaster, may appear misguided, as black individuals continue to be unfairly rejected in their endeavors to receive financial loans. ${ }^{61}$ As such, the

${ }^{59}$ Germain, "'Presidents of Color,' Globalization, and Social Inequality," 457.

${ }^{60}$ Monique W. Morris, "Discrimination and Mortgage Lending in America: A Summary of the Disparate Impact of Subprime Mortgage Lending on African Americans," National Association for the Advancement of Colored People, 2009, 6, http://naacp.3cdn.net/4ca760b774f81317c4 klm6i6yxg.pdf.

${ }^{61}$ Germain, "'Presidents of Color,' Globalization, and Social Inequality,” 457. descriptors of a rising black middle class may have failed to take a holistic consideration of the current situation. While some areas have seen certain improvements for black individuals (such as the increase in the percentage of government jobs), the large majority continue to be discriminated against and racially dispossessed through the continual promotion of whiteness and their accompanying discriminatory tirade.

Finally, an additional, yet brief consideration pertaining to the emergence of a supposed racial equality may also be interpreted as a commentary on the prevailing weakness of whiteness. That is to say, given the election of President Obama and the presumed surfacing of a prominent black middle class, one may justifiably begin to question the inherent societal dominance that has so often been equated to whiteness. Therefore, and as witnessed in the examples presented throughout the paper (particularly in regards to the education system), the introduction of neoliberal policies such as privatization, market deregulation, and a reduction in government interference, may be understood as a response to the assumed impotence of whiteness, and to reposition whites as the supreme, dictatorial power. ${ }^{62}$

\footnotetext{
${ }^{62}$ Shona Hunter, Elaine Swan, and Diane Grimes, "Introduction: Reproducing and Resisting Whiteness in Organizations, Policies, and Places," Social Politics 17, no. 4 (2010): 408, http://ehis.ebscohost.com.login.ezproxy.libr ary.ualberta.ca/eds/pdfviewer/pdfviewer?sid $=9 \mathrm{a} 5 \mathrm{ab} 361-0 \mathrm{a} 05-4973-\mathrm{bec} 5-$ $152 \mathrm{a} 84 \mathrm{e} 36 \mathrm{a} 31 \% 40$ sessionmgr $10 \& \mathrm{vid}=3 \& \mathrm{hi}$ $\mathrm{d}=103$.
} 


\section{Conclusion}

Therefore, given all of the information presented above, it becomes evident that dynamic and oppressive race relations remain pervasive throughout American society. This continued relevance of race privilege may be attributed to the subtle and strategic implementation of policies and practices that have established barriers to advancement within black communities. However, largely unnoticed by the public at large, these racialized actions have been allowed to persist. As alluded to throughout the essay, black individuals have incomparably higher rates of illiteracy, unemployment, and incarceration, while also occupying one of the lowest economic rungs of society. Moreover, through the images and portrayals of black men in the media and the method in which police officers racially profile potential victims, black individuals are unjustly portrayed as inherently more dangerous and violent than their white counterparts. In instances where these inequalities and fictitious portrayals have sought to have been rectified and corrected (as in the case of affirmative action), white individuals have constructed a figurative cement wall of protest and disapproval that seeks to maintain this racially tainted, almost dictatorial, discourse. As such, this has continued to plague the complete and genuine liberation of black individuals, while perpetuating the debilitating and fragmenting social construction that Africa-Americans are somehow inherently inferior.

However, the most dangerous narrative to accept is that race relations have equalized and that any resulting inequalities can simply be attributed to a lack of effort on the part of AfricanAmericans. Although largely motivated by the election of the first black President, certain conceptions of immigration have also aided in the construction of this misinformed understanding. To elaborate, Bean et all caution that, "because boundaries are loosening for some nonwhite groups, this could lead to the erroneous conclusion about progress in blackwhite relations in the United States."63 The drawbacks of such an understanding will continue to perpetuate this unrecognized, yet blatantly deliberate assault on the livelihood of African-Americans.

It is crucial to conclude that all of this is not meant to convey that hope and opportunity for progress are mere illusory notions. Toni Morrison, the prolific African-American novelist, eloquently advances the following optimistic, yet constrained outlook for the future of black individuals: "Our future is ripe, outrageously rich in its possibilities. Yet unleashing the glory of that future will require difficult labor." ${ }^{\text {"64 }}$ If the "difficult labor" were to manifest into a unified call to both government and

\footnotetext{
${ }^{63}$ Frank Bean, Cynthia Feliciano, Jennifer Lee, and Jennifer Van Hook, "The New U.S. Immigrants: How Do They Affect Our Understanding of the African American Experience?" ANNALS of the American Academy of Political and Social Science 621, no. 1 (2009): 215, http://ann.sagepub.com.login.ezproxy.librar y.ualberta.ca/content/621/1/202.full.pdf + ht $\mathrm{ml}$.

${ }^{64}$ As cited in Perry, More Beautiful and More Terrible, 183.
} 
the public at large, perhaps a conscious endeavor would have to be undertaken to address the aforementioned injustices of whiteness. This pressure for accountability may mitigate the rapacious assault on the black community and truly nurture the establishment of an environment that fosters equality, in tandem with the promotion of a genuine, racial acceptance. 


\section{Bibliography:}

Baum, Bruce. The Rise and Fall of the Caucasian Race: A Political History of Racial Identity. New York: New York University Press, 2006.

Bean, Frank, Cynthia Feliciano, Jennifer Lee, and Jennifer Van Hook. "The New U.S. Immigrants: How Do They Affect Our Understanding of the African American Experience?" ANNALS of the American Academy of Political and Social Science 621, no. 1 (2009): 202-220.

http://ann.sagepub.com.login.ezproxy.library.ualberta.ca/content/621/1/202.full.pdf +html.

Buras, Kristen L. "Race, Charter Schools, and Conscious Capitalism: On the Spatial Politics of Whiteness as Property (and the Unconscionable Assault on Black New Orleans)." Harvard Educational Review 81, no. 2 (2011): 296-331. http://www.metapress.com.login.ezproxy.library.ualberta.ca/content/6142343qqw36 0j03/?p=934a793b7711450690b360889fc3098f\&pi=8.

Bush, Melanie E. Everyday Forms of Whiteness: Understanding Race in a "Post-Racial" World. Lanham: Rowman \& Littlefield Publishers Inc, 2011.

Cazenave, Noel A. The Urban Racial State: Managing Race Relations in American Cities. Lanham: Rowman \& Littlefield Publishers Inc, 2011.

Dhamoon, Rita, and Yasmeen Abu-Laban. "Dangerous (Internal) Foreigners and Nation-Building: The Case of Canada." International Political Science Review 30, no. 2 (2009): 163-183.

Du Bois, W.E.B. Black Reconstruction in America: 1860-1880. West Hanover: Atheneum Publishers, 1979.

Fanon, Franz. Black Skin, White Masks. London: Pluto, 1986.

Fiske, John. Media Matters: Race and Gender in U.S. Politics. Minneapolis: University of Minnesota Press, 1996.

Frankenburg, Ruth. White Women, Race Matters: The Social Construction of Whiteness. Minneapolis: University of Minnesota Press, 1993.

Frye, Marilyn. "White woman feminist." In Overcoming Racism and Sexism, edited by Linda A. Bell and David Blumenfeld, 113-134. Lanham: Rowman \& Littlefield Publishers Inc, 1995.

Gabriel, John. Whitewash: Racialized Politics and the Media. New York: Routledge, 2005. 
Garner, Steve. Whiteness: An Introduction. New York: Routledge, 2007.

Germain, Felix. "'Presidents of Color,' Globalization, and Social Inequality." Journal of Black Studies 40, no. 3 (2010): 445-461.

http://jbs.sagepub.com.login.ezproxy.library.ualberta.ca/content/40/3/445.

Gillborn, David. "Coincidence or conspiracy? Whiteness, policy and the persistence of the Black/White achievement gap." Educational Review 60, no. 3 (2008): 229-248. http://www.informaworld.com.login.ezproxy.library.ualberta.ca/openurl?genre=artic le\&id=doi:10.1080/00131910802195745.

Herman, Edward S, and Noam Chomsky. Manufacturing Consent: The Political Economy of the Mass Media. London: Verso, 1994.

Hunter, Shona, Elaine Swan, and Diane Grimes. "Introduction: Reproducing and Resisting Whiteness in Organizations, Policies, and Places." Social Politics 17, no. 4 (2010): 407-422.

http://ehis.ebscohost.com.login.ezproxy.library.ualberta.ca/eds/pdfviewer/pdfviewe r?sid=9a5ab361-0a05-4973-bec5$152 \mathrm{a} 84 \mathrm{e} 36 \mathrm{a} 31 \% 40$ sessionmgr10\&vid=3\&hid=103.

Kaiser Family Foundation. "Race, Ethnicity, and Health Care Fact Sheet." 2006. http://www.kff.org/minorityhealth/upload/ 7541.pdf.

Kendall, Frances E. Understanding White Privilege: Creating Pathways to Authentic Relationships Across Race. New York: Routledge, 2006.

Klein, Naomi. "Minority Death Match: Jews, Blacks, and the 'Post-rcial' Presidency." Harper's Magazine, September 2009, 53-67.

Lipson, Daniel N. "The Resilience of Affirmative Action in the 1980s: Innovation, Isomorphism, and Institutionalization in University Admissions." Political Research Quarterly 64, no. 1 (2011): 132-144.

http://ehis.ebscohost.com.login.ezproxy.library.ualberta.ca/eds/pdfviewer/pdfviewe r?sid=18bcb162-1410-4fbd-ae422662 bed $85365 \% 40$ sessionmgr $113 \&$ vid=9\&hid $=103$.

Martinot, Steve. The Machine of Whiteness: Studies in the Structure of Racialization. Philadelphia: Temple University Press, 2010.

Morris, Monique W. "Discrimination and Mortgage Lending in America: A Summary of the Disparate Impact of Subprime Mortgage Lending on African Americans." National Association for the Advancement of Colored People, 2009. http://naacp.3cdn.net/4ca760b774f81317c4_klm6i6yxg.pdf. 
Perry, Imani. More Beautiful and More Terrible: The Embrace and Transcendence of Racial Inequality in the United States. New York: New York University Press, 2011.

Pew Research Center. A Year After Obama's Election: Blacks Upbeat about Black Progress, Prospects. Washington, DC: Author, 2010.

Phoenix, Ann. 'I'm white - so what?' The Construction of Whiteness for Young Londoners." In Off White, edited by Michelle Fine, Lois Weis, Linda Powell Pruitt, and April Burns, 187-197. New York: Routledge, 1997.

Riviera, Amaad, Jeannette Huezo, Christina Kasica, and Dedrick Muhammad. "State of the Dream 2009: The Silent Depression." United for a Fair Economy, 2009. http://www.faireconomy.org/files/pdf/state_of_dream_2009.pdf.

Twine, France W. A White Side of Black Britain: Interracial Intimacy and Racial Literacy. London: Duke University Press, 2010.

Viacom Media Networks. "Our Brands." In Reaching Our Global Audience. http://www.viacom.com/ourbrands/Pages/default.aspx. 